\title{
EFFICIENCY OF HYGIENIC BEHAVIOR OF WEST-EUROPEAN ECOTYPE HONEY BEE ${ }^{1}$
}

\author{
N. Nedić, M. Mladenović, S. Rašić, Z. Stojanović ${ }^{2}$
}

\begin{abstract}
Honeybee has wide area of spreading with few important races. Our honeybee (Apis mellifera carnica) belongs to southeast-European group, and because of its wide spreading, its populations are undergoing variations and lots of ecotypes with different morphologic and biologic characteristics are found.

For modern apiculture certain lines of ecotypes that have very good production properties are important, and where its hygienic behavior is studied.

Experiment was done on bee societies placed in LR beehives with ten frames. Hygienic behavior was studied in two lines of honeybees ( $G$ and $K$ ) in interval 24/48 hours. Based on obtained results it was determined that bee societies of line $\mathrm{G}$ had for $14.25 \%$ (after $24 \mathrm{~h}$ ), and $15.05 \%$ (after $48 \mathrm{~h}$ ) more expressive hygienic behavior considering line $\mathrm{K}$.
\end{abstract}

Key words: honeybee, hygienic behavior, ecotype

\section{Introduction}

Varroa destructor is one of the most distributed parasytes of honey bee and synthetic acaricides are mostly used for their control (Konstatinović et al., 1994; Nedić et al., 2002). This Inoxidae increases resistance with regard to traditional varroacides every year. Their use carries great risk of occurrence of residue in honey, wax and propolis and because of that its use is increasingly restrictive. Besides these failures, the occurrence of the resistance of varroa to chemical synthetic preparations is increasing.

However, the selection of more resistant bees, with hygienic behaviour can represent the solution of the problem of diseases in bee colonies. Selection of bees with better defense mechanism will enable longer period of tolerance to diseases with regard to unselectioned bee colonies.

Hygienic behaviour of bees is defined through natural resistence of bees towards the instigators of American plague disease (Rothenbuhler, 1964) and lime brood (Spivak and Gilliam 1998a, 1998b). The bees with hygienic behaviour discover fast and eliminate diseased larvae and cocoons from the colony. They also discover the diseased cocoons infested with the Inoxidae Varroa destructor (Peng et al., 1987; Boecking and Drescher, 1991). Bees open and eliminate infested individuals with varroa 4 to 7 days after the capping of cells (Spivak 1996; Thakur et al., 1997).

Elimination of infested cocoons limits the brood of varroa and interrupts its development cycle (Fries et al., 1994). Hygienic behaviour of bees is determined by two genic loci, one of which is controlled by the uncapping of the diseased brood, and the other by content elimination. However, a small number of colonies exhibits a high level of hygienic behaviour due to the recessive inheritance of this characteristic.

\section{Material and method}

The experiment was conducted on a bee hive in the vicinity of Kraljevo. In the experiment, bee colonies of domestic carnica (Apis mellifera carnica) were used, placed in the standard ten-frame LR bee hives. Bee colonies originated from two different lines, and their mother queen bees originated from different regions of Serbia.

Hygienic behaviour was tested according to pin-killed method, with one frame with open brood extracted from each bee hive and a rhomboid including 100 worker bee cells was placed on it. After that, with one prick with entomological needle, cocoons were sacrificed in a marked field. The frames were returned to the bee hive and after 24 , i.e. 48 hours reading was conducted.

1 Original scientific paper - supported by the Ministry of Science and Technology, Project no. BTR 5.02.0404.B - Originalni naučni rad je finansiran od strane Ministarstva za nauku i tehnologiju Projektom broj: BTR 5.02.0404.B

2 Nebojša Nedić, MSc, asisstant, Mića Mladenović, PhD, professor, Slađan Rašić, BSc Eng, professional associate, Faculty of Agriculture Belgrade-Zemun. Zoran Stojanović, BSc Biol. Center for Honey Bee Selection, Timočka 6, Kraljevo 


\section{Results and discussion}

The results of studying hygienic behavior in two lines of honey bee, during 24 hours, have been presented in table 1 . Line $\mathrm{G}$ bees showed greater instinct of hygienic behaviour and after 24 hours they had by 5.91 more clean cells on an average. However, this difference was statistically insignificant.

Our results are in accordance with the results of Woyke et al. (2004) stating that the hygienic behaviour of bees varied in wide range from 37 to 74\%. Spivak and Downey (1998) in their research state that the hygienic behaviour was $61.6 \%$, while in Starline it was $49.9 \%$. However, the stated differences occurred above all as a consequence of planned work on the selection of colonies with non-hygienic behaviour and are not the consequence of innitial selection of different populations of honey bee.

Table 1. Results of hygienic behavior of bees after 24 hours

Tabela 1. Rezultati ispitivanja higijenskog ponašanja pčela nakon 24 sata

\begin{tabular}{|l|c|c|c|}
\hline Line & No. of colonies & Average uncapped cells & $\mathrm{F}_{\text {exp. }}$ \\
\hline $\mathrm{G}$ & 8 & 47,37 & $0,56^{\text {ns }}$ \\
\hline $\mathrm{K}$ & 13 & 41,46 & \\
\hline
\end{tabular}

After 48 hours $\mathrm{G}$ line (table 2 ) had 8.6 cleaner cells in comparison with the $\mathrm{K}$ line. In comparison with the first period of monitoring, in the following 24 hours bee lines cleaned $18.38(\mathrm{G})$, i.e. $15.69(\mathrm{~K})$ more cells, which represents $38.80 \%$, i.e. $37.84 \%$ increase. Statistically non significant differences were established in hygienic behaviour between two different lines in $24 / 48$ hours period.

However, Pejović (2001) states the efficiency of elimination of damaged cocoons of $91.45 \%$ in bee colonies in Mačva and $93.60 \%$ in bees from Rudnik, while Spivak (1996) states the value of $60 \%$ for hygienic behaviour. A high percentage of clean cells can be a consequence of greater presence of bees of medium age younger than collectors (Arathi et al., 2000), but also greater damages on tested cells (Woyke et al., 2004).

Table 2. Results of hygienic behavior of bees after 48 hours

\begin{tabular}{|l|c|c|c|}
\hline Line & No. of colonies & Average uncapped cells & $\mathrm{F}_{\text {exp. }}$ \\
\hline $\mathrm{G}$ & 8 & 65,75 & $1,62^{\mathrm{ns}}$ \\
\hline $\mathrm{K}$ & 13 & 57,15 & \\
\hline
\end{tabular}

\section{Conclusion}

Based on testing hygienic behaviour of honey bee of the West European ecotype, we can conclude that $\mathrm{G}$ bee lines cleaned $14.25 \%$ in 24 hours, and in 48 hours $15.05 \%$ more cells than $\mathrm{K}$ bee lines. The determined differences were statistically insignificant with regard to high variation within the observed treatments. The studies determined that both bee lines cleaned around 1/3 more cells between 24 and 48 hours.

The natural potential of honey bee of the West European region with regard to hygienic behaviour represents the basis of further selection work, since this characteristic is closely related to the resistence towards the Inoxidae varroa. High variability of this characteristic in the populations of our honey bee offers the possibility of selection of colonies with highly pronounced hygienic behaviour, thereby not neglecting other economically important characteristics of productivity, temperament and dilligence.

\section{EFIKASNOST HIGIJENSKOG PONAŠANJA MEDONOSNE PČELE ZAPADNOSRBIJANSKOG EKOTIPA}

N. Nedić, M. Mladenović, S. Rašić, Z. Stojanović

\section{Rezime}

Medonosna pčela ima širok areal rasprostranjenja sa nekoliko privredno značajnih rasa. Naša medonosna pčela (Apis mellifera carnica) pripada jugoistočno - evropskoj grupi i zbog širokog rasprostranjenja 
poseduje značajno variranje populacija, te se zbog toga javlja više ekotipova, sa posebnim morfološkim i biološkim osobinama

Za savremeno pčelarstvo posebno su značajne određene linije ekotipova koje se odlikuju dobrim proizvodnim osobinama, pored kojih se prati njihovo higijensko ponašanje.

Ogled je izveden na pčelinjim društvima smeštenim u desetoramnim LR košnicama. Ispitivano je higijensko ponašanje kod dve linije medonosnih pčela (G i K) u razmaku 24/48 sati. Na osnovu rezultata istraživanja utvrđeno je da su pčelinja društva linije G imala za 14,25\% (nakon 24 h), odnosno za 15,05\% (nakon 48h) izraženije higijensko ponašanje u odnosu na liniju K.

Ključne reči: medonosna pčela, higijensko ponašanje, ekotip

\section{References}

1. ARATHI H.S., BURNS I., SPIVAK M. (2000): Ethology of hygienic behaviour in the honey bee Apis mellifera L. (Hymenoptera:Apidae): Behavioural Repertoire of hygienic bees. Ethology 106: 365-379.

2. BOECKING O., DRESCHER W. (1992): The removal responses of Apis mellifera L. colonies to brood in wax and plastic cells after artificial and natural infestation with Varroa jacobsoni Oud. and to freeze killed brood. Experimental Applayed Acarology 16: 321-329.

3. FRIES I., CAMAZINE S., SNEYD J. (1994): Population dynamics of Varroa jacobsoni: a model and a rewiev. Bee World 7:5-28.

4. KONSTANTINOVIĆ B., MLADENOVIĆ M. (1985): A contribution to the investigation of thermic treatment of bees societies in the fight against Varroa jacobsoni. XXX International apicultural congress (Apimondia 85), Nagoya, Japan.

5. NEDIĆ N., MLADENOVIĆ M., POPESKOVIĆ D., GEORGIJEV ANETA, MIRJANIĆ G. (2002): The influence of copper gluconate on the control of Varroa jacobsoni. XV Innovations in livestock breeding 2002, Biotechnology in livestock breeding, 18, 5-6, 329-332.

6. PEJOVIĆ D. (2001): Testing hygienic and nursing behaviour of bee of Apis mellifera carnica subspecies in the function of its resistence to diseases. MSc thesis. Faculty of Veterinary Medicine of the University of Belgrade, pp 1-174.

7. PENG Y.S., FANG Y., XU S., GE L., NASR E.M. (1987):Response of foster Asian honey bee (Apis cerana Fabr.) colonies to the brood of European honey bee (Apis mellifera L) infested with parasitic mite Varroa jacobsoni Oudemans. Journal of Inveretebrata Pathology 49: 251-264.

8. ROTHENBUHLER W.C. (1964): Behavior genetics of nest cleaning in honey bees. IV Responses of $F_{1}$ and backcross generations to disease killed brrod. American Zoology 4: 111-123.

9. SPIVAK M. (1996): Hygienic behaviour and defense against Varroa jacobsoni. Apidiologie 27: 245-260.

10. SPIVAK M., DOWNEY D. (1998): Field assays for hygienic behavior in honey bees (Hymenoptera : Apidae). Journal of Econ. Entomology 91: 64-70.

11. SPIVAK M., GILLIAM M. (1993): Facultative expression of hygienic behavior of honey bees in relation to disease resistance. Journal of Apiculture Research 32: 143-147.

12. SPIVAK M., GILLIAM M. (1998a):Hygienic behaviour of honey bees and its application for control of brood diseases and varroa mites. Part I: Hygienic behaviour and resistance to American foulbrood. Bee World 79: 124-134.

13. SPIVAK M., GILLIAM M. (1993): Hygienic behaviour of honey bees and its application for control of brood diseases and Varroa mites. Part II: Studies on hygienic behaviour since the Rothenbuhler era. Bee World 79: 165-182.

14. THAKUR R., BIENEFELD K., KELLER R. (1997): Varroa defense behavior in A. mellifera carnica. American Bee Journal 137: 143-148.

15. WOYKE J., WILDE J., REDDY C.C. (2004): Open air nesting honey bees Apis dorsata and Apis laboriosa differ form the cavity nesting apis mellifera and Apis cerana in brood hygiene behaviour. Journal of Invertebrate Pathology 86: 1-6. 